\title{
INFLUENCE OF SOIL MOISTURE DEFICIT AND POTASSIUM FERTILIZATION ON WATER RELATIONS AND PRODUCTIVITY OF SOME SUGARCANE VARIETIES
}

\author{
(Received:5.5.2011) \\ By \\ M.A. Bekheet \\ Sugar Crops Research Institute, Agriculture Research Center, Giza, Egypt
}

\begin{abstract}
Two field experiments were carried out at Shandaweel Research Station, Sohag Governorate in 2008/2009 and 2009/2010 seasons to study the influence of twenty-seven treatments representing the combinations of three irrigation regimes (applying irrigation water at 75-80, 60-65 and 45-50\% of field capacity), three potassium fertilization levels (48, 72 and $96 \mathrm{~kg} \mathrm{~K}_{2} \mathrm{O} / \mathrm{fed}$.) and three sugarcane varieties (the commercial, G.T.54-9 variety and two promising ones viz. Ph.8013 and G.84-47). A split-split plot design with three replications was used.

The results showed that irrigating sugarcane at $60-65 \%$ FC resulted in the tallest and thickest cane stalks, the highest number of millable canes and cane and sugar yields/fed., while the highest percentages of brix, sucrose and sugar recovery were recorded at 45-50\% FC. Water consumptive use (CU) was 8307.1 and $7621.4 \mathrm{~m}^{3} / \mathrm{fed}$., when sugarcane was irrigated at $75-80 \%$ and $45-50 \%$ FC, respectively. The highest CU was recorded by Ph.8013, while the highest WUE was recorded by G. 84-47.

Sugarcane G.84-47 variety showed significant superiority over the other ones in the number of millable canes, cane and sugar yields/fed as well as brix \%, sucrose \% and sugar recovery\%.

Raising K-fertilization level from 48 to 72 and $96 \mathrm{~kg} \mathrm{~K}_{2} \mathrm{O} / \mathrm{fed}$. led to a gradual increase in stalk height and diameter, number of millable canes, and cane and sugar yields/fed. as well as brix \%, sucrose\% and sugar recovery\%.

Under the conditions of the present investigation, planting G.84-47 sugarcane variety fertilized with $72 \mathrm{~kg} \mathrm{~K} \mathrm{~K}_{2} \mathrm{O} /$ fed. and irrigated at $60-65 \% \mathrm{FC}$ can be recommended to obtain the highest cane and sugar yields/fed.
\end{abstract}

Key words: Potassium fertilization, productivity, soil moisture deficit, sugar cane, water relations.

\section{INTRODUCTIOIN}

Irrigation is a major factor affecting, germination, tillering, boom stage, sugar accumulation and hence cane and sugar yields. In this respect, sugar cane is adversely affected by water logging which creates some problems including leaching of water by percolation and available nutrients beyond root zone, lodging, pests and diseases and harvesting difficulties. In addition, excessive application of water causes inadequate soil aeration and low water potential. As for soil moisture effect on sugarcane, Altaf UrRahman et al. (1998) found that when sugarcane was irrigated at 40, 60 and $80 \%$ available soil moisture (ASM), sugar yield decreased with decreasing water availability, while juice quality increased. Abdel Wahab (2005) found that irrigating at 55-60\% ASM depletion gave the highest cane yield. Ibrahim (2006) tested three sugarcane irrigation treatments $\mathrm{M} 1$ : irrigating sugarcane when $40-50 \%$ of ASM was depleted; M2: irrigating sugarcane when $80-90 \%$ ASM was depleted and M3: irrigating sugarcane when 90$100 \%$ ASM was depleted. He mentioned that irrigation treatments significantly affected the length of the irrigation intervals, number of irrigations, cane and sugar yields and sucrose recovery $\%$. He added that M1 gave the highest cane yield and that delaying irrigation beyond $70 \%$ depletion of ASM is detrimental to the growth of sugarcane and will result in economic losses of sugar yield.

It is known that the differences among genotypes and varieties are attributed to the variation in foliage size (leaf area), number of stomata on both sides of leaves, thickness of cuticle (wax layer). Most references emphasized that the potential of cane variety is the corner stone 
in the recoverable sugar yield per unit area. Potassium fertilizer plays a direct effect on juice quality of sugarcane. Potassium has a function as an activator in protein metabolism and for several enzymes in carbohydrate metabolism. It is also involved in turgor control in specialized cells, and in turn the water balance status of plants. The balance between the applied water and the recommended dose of nitrogen and potassium given to sugarcane could be changed specially under the various varieties. Concerning varietal differences, El-Shafai and Ismail (2006) showed that the commercial sugarcane cv. G.T.54-9 was superior in stalk height, number of millable cane and cane and sugar yields/fed. compared with Phil.8013, G.95-19 and G.95-21 varieties. ElSogheir et al. (2007) found that cvs. Phil.8013, G. 84-47 and G.98-28 in a descending order could be cultivated with and/or replaced with the main cane variety G.T.54-9 which yielded the best cane yield, juice quality and hence sugar yield per unit area. Ismail et al. (2008) showed that the tested sugarcane varieties significantly differed in all the studied traits except purity $\%$,cane and sugar yields. The commercial cv. G.T.54-9 showed superiority in stalk length, purity \%, sugar recovery $\%$ and sugar yields/fed. Ismail and ElSogheir (2008) reported that sugarcane varieties significantly differed in stalk length, stalk diameter, number of millable canes $/ \mathrm{m}$, cane yield/fed., sucrose $\%$, sugar recovery $\%$ and sugar yield. The highest cane yield was recorded by G.98-28 variety in both seasons. Ahmed et al. (2008) cleared that sugarcane variety G.84-47 surpassed the other two varieties (Phil.8013 and G.98-28) in millable cane number $/ \mathrm{m}^{2}$, stalk height, sugar recovery $\%$ and cane yield, meanwhile sugarcane variety Phli.8013 attained the highest value of stalk diameter, brix, sucrose and sugar yield.

Concerning potassium effect, it was reported that applying potassium fertilizer at 48 and $72 \mathrm{~kg}$ $\mathrm{K}_{2} \mathrm{O} /$ fed. recorded the highest millable cane and recoverable sugar yields (Abo El-Wafa et al., 2006; Bekheet, 2006; Elamin et al., 2007; Mahmoud et al., 2008 and Mokadem et al., 2010).

The aim of the present work was to find out the optimum soil moisture and K-fertilization levels for the tested sugarcane varieties to get the highest cane and sugar yields/fed.

\section{MATERIALS AND METHODS}

Two field experiments were carried out in Shandaweel Agricultural Research Station, at Sohag Governorate in 2008/2009 and 2009/2010 seasons to study the influence of soil moisture deficit and potassium fertilization levels on the water relations and productivity of some sugarcane varieties. Each field trial included twenty-seven treatments representing the combinations between three irrigation treatments, three potassium fertilizer levels and three sugarcane varieties.

\subsection{Irrigation treatments (A)}

1-Irrigation at 75-80 \% field capacity (FC). (a total number of 19 irrigation with an average interval of 17 days between irrigations).

2-Irrigation at 60-65\% field capacity (FC). (a total number of 17 irrigation with an average interval of 19 days between irrigations).

3-Irrigation at $45-50 \%$ field capacity (FC). (a total number of 15 irrigation with an average interval of 22 days between irrigations).

Soil moisture at the field capacity (FC) was determined as follows:

A plot area of $1.5 \times 1.5 \mathrm{~m}^{2}$ was watered for 6 hours until it was fully saturated and covered with a plastic sheet. Soil samples were taken every 12 hours to determine soil moisture \%. The moisture $\%$ that the soil keeps against gravity after 48 hours represents FC.

Irrigation water was applied when the soil moisture content reached the defined field capacity in each treatment. Borders of 1.5 -m width were ditched to prevent seepage among irrigation treatments. The application of irrigation treatments began after planting and the $1^{\text {st }}$ postplanting irrigations. Irrigation was withheld one month before harvesting.

\subsection{Sugarcane varieties $(B)$}

The promising varieties viz. Ph.8013 and G.8447 sugarcane varieties, in addition to the commercial cultivar G.T.54-9 as a control, were used.

\subsection{Potassium fertilizer levels $(\mathrm{C})$}

Potassium was applied at the rate of 48,72 and $96 \mathrm{~kg} \mathrm{~K} \mathrm{~K}_{2} \mathrm{O} / \mathrm{fed}$. as potassium sulphate ( $48 \%$ $\mathrm{K}_{2} \mathrm{O}$ ) with the second addition of nitrogen fertilizer at age of three months from planting.

A split-split plot design with three replications was used in both growing seasons. Irrigation treatments were allocated in the main plots. Sugarcane varieties were randomly distributed in the sub plots, while potassium levels were distributed in the sub-sub plots. The experimental unit area was $21 \mathrm{~m}^{2}$, including 6 ridges of $3.5 \mathrm{~m}$ in length and $1.0 \mathrm{~m}$ apart. Sugarcane varieties were planted during the $2^{\text {nd }}$ week of March and harvested after 12 months in both experiments. 
Phosphorus was applied at the rate of $30 \mathrm{~kg}$ $\mathrm{P}_{2} \mathrm{O}_{5}$ during seed bed preparation as calcium super phosphate $\left(15 \% \mathrm{P}_{2} \mathrm{O}_{5}\right)$. Nitrogen, as urea $(46 \% \mathrm{~N})$ was added at the rate of $210 \mathrm{~kg} \mathrm{~N} / \mathrm{fed}$. in two equal doses, after 50 and 90 days from planting. The previous crop was sesame followed by fallow. Laser land levelling was practiced at $0.05 \mathrm{~m} / 100$ $\mathrm{m}$ to control water supply. All other agricultural practices were carried out as recommended.

Soil moisture constants of the experimental site are presented in Table (1).

Table (1): Field capacity, available soil moisture,welting point and bulk density of the experimental site.

\begin{tabular}{|c|c|c|c|c|}
\hline $\begin{array}{c}\text { Soil } \\
\text { depth } \\
(\mathbf{c m})\end{array}$ & $\begin{array}{c}\text { Field } \\
\text { capacit } \\
\mathbf{y}(\boldsymbol{\%})\end{array}$ & $\begin{array}{c}\text { Welting } \\
\text { point } \\
(\boldsymbol{\%})\end{array}$ & $\begin{array}{c}\text { Available } \\
\text { soil } \\
\text { moisture } \\
(\boldsymbol{\%})\end{array}$ & $\begin{array}{c}\text { Bulk } \\
\text { density } \\
\left(\mathbf{g} / \mathbf{c m}^{\mathbf{3}}\right)\end{array}$ \\
\hline $\mathbf{0}-\mathbf{1 5}$ & 34.50 & 18.50 & 16.00 & 1.19 \\
\hline $\mathbf{1 5}-\mathbf{3 0}$ & 33.00 & 17.30 & 15.50 & 1.24 \\
\hline $\mathbf{3 0}-\mathbf{4 5}$ & 31.50 & 16.40 & 15.10 & 1.28 \\
\hline $\mathbf{4 5}-\mathbf{6 0}$ & 30.00 & 15.45 & 14.55 & 1.35 \\
\hline
\end{tabular}

Chemical and physical properties of the experimental soil are presented in Table (2).

Table (2):Soil physical and chemical properties of the upper $45 \mathrm{~cm}$ of the experimental sites.

\begin{tabular}{|c|c|c|}
\hline \multirow{3}{*}{$\begin{array}{l}\text { Physical } \\
\text { analysis }\end{array}$} & sand $\%$ & 25.46 \\
\hline & Silt \% & 43.45 \\
\hline & Clay $\%$ & 31.09 \\
\hline \multicolumn{2}{|c|}{ Soil texture } & Clay loam \\
\hline & Total N (\%) & 0.196 \\
\hline & $\mathrm{CaCO}_{3} \%$ & 1.26 \\
\hline & \multicolumn{2}{|c|}{$\begin{array}{c}\text { Soluble ions }\{\text { meq/100 g soil } \\
(1: 5)\}\end{array}$} \\
\hline & $\mathrm{CO}_{3}^{-}$ & - \\
\hline & $\mathrm{H} \mathrm{CO}_{3}^{-}$ & 0.30 \\
\hline & $\mathrm{Cl}^{-}$ & 0.88 \\
\hline & $\mathrm{SO}_{4}{ }^{=}$ & 1.02 \\
\hline & $\mathrm{Ca}^{++}$ & 0.52 \\
\hline & $\mathrm{Mg}^{++}$ & 0.26 \\
\hline & $\mathrm{Na}^{+}$ & 1.26 \\
\hline & $\mathrm{K}^{+}$ & 0.16 \\
\hline & $\mathrm{EC}(\mathrm{ds} / \mathrm{m})$ & 0.263 \\
\hline & $\mathrm{pH}(1: 1)$ & 7.3 \\
\hline
\end{tabular}

Soil analysis was done according to the method described by Jackson (1973).

\section{The recorded data}

At harvest, 20 plants were randomly collected from each sub-sub plot to determine the following traits:

\section{Growth traits}

1. Stalk height $(\mathrm{cm})$ was measured from soil surface to the top visible dewlap;

2. Stalk diameter $(\mathrm{cm})$ was measured at the middle part of stalks.

Millable cane and cane yield/fed.

Plants of the four guarded rows were harvested, cleaned, topped and weighed to estimate the following parameters:

3. Number of millable canes/fed.

4. Cane yield (ton/fed.).

Quality traits

5. Brix percentage (total soluble solids, TSS \%) in juice was determined using Brix Hydrometer standardized at $20^{\circ} \mathrm{C}$.

6. Sucrose $/ 100 \mathrm{~cm}^{3}$ juice was determined using Saccharemeter according to A.O.A.C. (1995).

Purity $\%=$ sucrose $\% /$ brix $\%$ x 100

7. Sugar recovery percentage was calculated according to the equation outlined by Yadav and Sharma (1980):

Sugar recovery $\%=[$ sucrose $\%-0.4$ (brix $\%$ sucrose \%)] x 0.73 .

8. Sugar yield (ton/fed.) was computed according to the following equation:

Sugar yield $=$ cane yield (tons/fed.) $\mathrm{x}$ sugar recovery $\%$.

\section{Water relations}

\section{Water consumptive use (CU)}

It was estimated by using the soil sampling method and calculated according to the technique used and according to the equation of Israelsen and Hansen (1962).

$\mathrm{CU}=\mathrm{D} \times \mathrm{B}_{\mathrm{d}} \mathrm{x}(\mathrm{Q} 2-\mathrm{Q} 1) / 100$

Where:

$\mathrm{CU}=$ water consumptive use $(\mathrm{cm})$ in the effective root zone $(60 \mathrm{~cm})$.

$\mathrm{D}=$ Soil layer depth.

$\mathrm{B}_{\mathrm{d}}=$ Soil bulk density $\left(\mathrm{g} / \mathrm{cm}^{3}\right)$.

$\mathrm{Q}_{1}=$ Soil moisture $\%$, before irrigation.

$\mathrm{Q}_{2}=$ Soil moisture \%, 48 hours after irrigation.

Water use efficiency (WUE)

It was calculated on cane and sugar basis as shown by Vites (1965) as follows:

1. WUE $\left(\mathrm{kg}\right.$ cane $/ \mathrm{m}^{3}$ water $)=$ cane yield $\left(\mathrm{kg} / \mathrm{fed}\right.$.)/water consumptive use $\left(\mathrm{m}^{3} / \mathrm{fed}\right.$.).

2. WUE ( $\mathrm{kg}$ sugar $/ \mathrm{m}^{3}$ water $)=$ sugar yield ( $\mathrm{kg} / \mathrm{fed}$.)/water consumptive use $\left(\mathrm{m}^{3} / \mathrm{fed}\right.$.).

The collected data were statistically analyzed as mentioned by Gomez and Gomez (1984) using "MSTAT-c" computer software package according to Freed et al. (1989).

\section{RESULTS AND DISCUSSIONS}

\subsection{Stalk height and diameter}


Results in Table (3) clear that irrigating sugarcane at $60-65 \%$ FC significantly resulted in the tallest and thickest cane stalks in both seasons. Applying irrigation at $45-50 \%$ FC gave the shortest stalks in the $1^{\text {st }}$ season. On the other hand, it was found that applying irrigation at $75-80 \%$ FC gave the lowest mean value of stalk diameter, while irrigating sugarcane at $45-50 \%$ FC produced medium values of this trait, in the $1^{\text {st }}$ season. In the $2^{\text {nd }}$ one, insignificant differences were detected in cane stalk height and diameter in case of applying irrigation water using the $1^{\text {st }}$ irrigation regime (at $75-80 \% \mathrm{FC}$ ) or the $3^{\text {rd }}$ one $(45-50 \%$ FC). These results are in agreement with those reported by Ibrahim (2006).

The tested sugarcane varieties varied significantly in stalk height and diameter in both seasons. The commercial G.T.54-9 variety had the highest stalks among the three varieties, followed by G.84-47 and Ph.8013 which recorded the lowest values in this trait. However, the difference between G.84-47 and $\mathrm{Ph} .8013$ varieties in stalk height was insignificant in the $2^{\text {nd }}$ season. On the other hand, Ph.8013 variety had the thickest stalks, while G.84-47 variety recorded the lowest value of this growth character. Meantime, G.T.549 had moderate stalk diameter. The variance among cane varieties in these traits may be due to their gene make-up. El-Shafai and Ismail (2006); El-Sogheir et al. (2007); Ismail et al. (2008) and Ahmed et al. (2008) recorded differences among the tested cane varieties in stalk height and diameter.

Raising potassium fertilization level from 48 to 72 and $96 \mathrm{~kg} \mathrm{~K} \mathrm{~K}_{2} \mathrm{O} / \mathrm{fed}$. attained significant increases in both stalk height and diameter in the $1^{\text {st }}$ and $2^{\text {nd }}$ seasons. These results may be due to the role of potassium in cell division, in addition to its role in activating protein synthesis and enzymes of carbohydrate building-up. These results are in agreement with those mentioned by Abo El-Wafa, et al. (2006); Bekheet (2006); Elamin et al. (2007); Mahmoud et al. (2008) and Mokadem et al. (2010).

Except for the interaction between irrigation and potassium levels in the $1^{\text {st }}$ season, stalk height was insignificantly influenced by the interactions among the studied factors in both seasons. Stalk diameter was affected by the interaction between irrigation and cane varieties in the $2^{\text {nd }}$ season.

\subsection{Number of millable canes and cane yield/fed.}

Numbers of millable canes and cane yield/fed. were significantly affected by the studied irrigation regimes (Table 4). Adding irrigation water to sugarcane at $60-65 \%$ FC attained the highest values of the two traits, while applying irrigation at $45-50 \%$ FC gave the lowest records, in both seasons. Irrigation at $60-65 \%$ FC attained 2.38 and 2.93 thousand stalks/fed. as well as 3.00 and 4.00 tons of canes/fed. higher than those obtained with irrigation at $75-80 \% \mathrm{FC}$ and $45-50 \% \mathrm{FC}$, respectively, in the $1^{\text {st }}$ and the $2^{\text {nd }}$ seasons, successively. It can be noticed that the higher values of cane stalk height, diameter and number of millable canes recorded at applying irrigation at $60-65 \% \mathrm{FC}$ compared to that given 75-80 \% FC and/or 45-50\% FC (Table 3 and 4) participated in getting the highest cane yield/fed.. These findings are in accordance with those found by Abdel Wahab (2005) and Ibrahim (2006).

Sugarcane G.84-47 variety significantly surpassed the other two varieties in the number of millable canes (in both seasons) and cane yield/fed. (in the $1^{\text {st }}$ season), while $\mathrm{Ph} .8013$ recorded the lowest values of the two traits in both seasons. The difference among cane varieties in these traits could be due to their gene make-up. El-Shafai and Ismail (2006), El-Sogheir et al. (2007), Ismail et al. (2008) and Ahmed et al. (2008) recorded differences among the tested cane varieties in these characters.

Gradual and significant increases in both number of millable canes and cane yield/fed. were gained by increasing the dose of potassium fertilizer in both seasons. Raising K-dose to $96 \mathrm{~kg}$ $\mathrm{K}_{2} \mathrm{O} /$ fed. increased the number of millable canes by 2.10 and 0.60 thousand/fed. In the $1^{\text {st }}$ season and by 2.11 and 0.77 thousand/fed. in the $2^{\text {nd }}$ one, correspond with those obtained by $48 \mathrm{~kg} \mathrm{~K}_{2} \mathrm{O} / \mathrm{fed}$. As well as cane yield was increased by 2.91 and 0.11 ton/fed. in the $1^{\text {st }}$ season and 2.50 and 0.10 ton/fed., in the $2^{\text {nd }}$ one, respectively. These results are probably due to the positive and beneficial role of $\mathrm{K}$ element which increased all of cane stalk height, diameter and number of millable canes, and hence increased the harvestable cane yield/fed. These results are in agreement with those reported by Abo El-Wafa et al. (2006), Bekheet (2006), Elamin et al. (2007), Mahmoud et al. (2008) and Mokadem et al. (2010).

Concerning the interaction effects, the number of millable canes and cane yield/fed. were significantly affected by the interaction between irrigation and both of potassium and cane varieties in both seasons. The interaction between cane varieties and $\mathrm{K}$ levels had a significant effect on the number of millable canes, in the $1^{\text {st }}$ season. Meantime,the number of millable canes/fed. was 
Table (3): Effect of irrigation, varieties, potassium levels and their interactions on stalk height and diameter (cm) in $2008 / 2009$ and 2009/2010 seasons.

\begin{tabular}{|c|c|c|c|c|c|c|c|c|c|c|c|c|c|c|c|c|c|}
\hline \multirow{4}{*}{$\begin{array}{c}\text { Irrigation } \\
\text { (A) }\end{array}$} & \multirow{4}{*}{$\begin{array}{c}\text { Sugar } \\
\text { cane } \\
\text { varieties } \\
(B) \\
\end{array}$} & \multicolumn{8}{|c|}{ Stalk height $(\mathrm{cm})$} & \multicolumn{8}{|c|}{ Stalk diameter $(\mathrm{cm})$} \\
\hline & & \multicolumn{4}{|c|}{ 2008/2009 season } & \multicolumn{4}{|c|}{ 2009/2010 season } & \multicolumn{4}{|c|}{ 2008/2009 season } & \multicolumn{4}{|c|}{ 2009/2010 season } \\
\hline & & \multicolumn{3}{|c|}{ Potassium $\mathrm{kg} \mathrm{K} \mathrm{K}_{2} \mathrm{O}$ fed. (C) } & \multirow{2}{*}{ Mean } & \multicolumn{3}{|c|}{ Potassium $\mathrm{kg} \mathrm{K}_{2} \mathrm{O}$ fed. $(\mathrm{C})$} & \multirow{2}{*}{ Mean } & \multicolumn{3}{|c|}{ Potassium $\mathrm{kg} \mathrm{K}_{2} \mathrm{O}$ fed. (C) } & \multirow{2}{*}{ Mean } & \multicolumn{3}{|c|}{ Potassium $\mathrm{kg} \mathrm{K}_{2} \mathrm{O}$ fed. (C) } & \multirow{2}{*}{ Mean } \\
\hline & & 48 & 72 & 96 & & 48 & 72 & 96 & & 48 & 72 & 96 & & 48 & 72 & 96 & \\
\hline \multirow{2}{*}{$\begin{array}{c}\text { At } \\
75-80 \% \\
\text { FC } \\
\end{array}$} & G.T.54-9 & 280.00 & 282.33 & 285.33 & 282.56 & 276.33 & 277.67 & 281.67 & 278.56 & 2.62 & 2.66 & 2.70 & 2.66 & 2.58 & 2.60 & 2.64 & 2.61 \\
\hline & G. 84-47 & 279.33 & 281.33 & 282.67 & 281.11 & 274.33 & 277.00 & 277.67 & 276.33 & 2.47 & 2.49 & 2.51 & 2.49 & 2.45 & 2.48 & 2.51 & 2.48 \\
\hline \multicolumn{2}{|c|}{ Mean } & 279.22 & 281.22 & 283.33 & 281.26 & 274.89 & 277.56 & 280.22 & 277.56 & 2.60 & 2.63 & 2.65 & 2.62 & 2.57 & 2.60 & 2.65 & 2.61 \\
\hline \multirow{2}{*}{$\begin{array}{c}\text { At } \\
60-65 \% \\
\text { FC }\end{array}$} & G.T.54-9 & 282.00 & 286.67 & 288.13 & 285.60 & 279.00 & 282.00 & 284.33 & 281.78 & 2.71 & 2.72 & 2.74 & 2.72 & 2.69 & 2.71 & 2.74 & 2.71 \\
\hline & G. 84-47 & 280.00 & 283.00 & 285.33 & 282.78 & 280.00 & 282.00 & 282.33 & 281.44 & 2.55 & 2.57 & 2.59 & 2.57 & 2.48 & 2.52 & 2.57 & 2.52 \\
\hline \multicolumn{2}{|c|}{ Mean } & 280.33 & 283.89 & 285.71 & 283.31 & 279.00 & 281.22 & 283.00 & 281.07 & 2.68 & 2.70 & 2.71 & 2.70 & 2.63 & 2.66 & 2.69 & 2.66 \\
\hline \multirow{3}{*}{$\begin{array}{c}\text { At } \\
45-50 \% \\
\text { FC }\end{array}$} & Ph 8013 & 275.00 & 275.67 & 277.00 & 275.89 & 270.00 & 276.67 & 277.00 & 274.56 & 2.70 & 2.71 & 2.75 & 2.72 & 2.64 & 2.67 & 2.70 & 2.67 \\
\hline & G.T.54-9 & 279.67 & 280.33 & 281.00 & 280.33 & 277.00 & 278.67 & 280.00 & 278.56 & 2.62 & 2.65 & 2.68 & 2.65 & 2.59 & 2.61 & 2.66 & 2.62 \\
\hline & G. 84-47 & 278.00 & 279.00 & 280.00 & 279.00 & 272.00 & 276.33 & 280.00 & 276.11 & 2.45 & 2.47 & 2.51 & 2.48 & 2.44 & 2.47 & 2.48 & 2.46 \\
\hline \multicolumn{2}{|c|}{ Mean } & 277.56 & 278.33 & 279.33 & 278.41 & 273.00 & 277.22 & 279.00 & 276.41 & 2.59 & 2.61 & 2.65 & 2.62 & 2.55 & 2.58 & 2.61 & 2.58 \\
\hline $\begin{array}{c}\text { Average } \\
\text { of } \\
\text { varieties }\end{array}$ & G. 84-47 & 279.11 & 281.11 & 282.67 & 280.96 & 275.44 & 278.44 & 280.00 & 277.96 & 2.49 & 2.51 & 2.53 & 2.51 & 2.45 & 2.49 & 2.52 & 2.49 \\
\hline \multicolumn{2}{|c|}{ Mean of potassium } & 279.04 & 281.15 & 282.79 & & 275.63 & 278.67 & 280.74 & & 2.62 & 2.64 & 2.67 & & 2.58 & 2.61 & 2.65 & \\
\hline \multicolumn{18}{|c|}{ LSD at 0.5 level for: } \\
\hline \multirow{2}{*}{\multicolumn{2}{|c|}{$\begin{array}{l}\text { Irrigation } \\
\text { Varieties }\end{array}$}} & & & & 0.66 & & & & 2.54 & & & & 0.03 & & & & 0.01 \\
\hline & & (B) & & & 1.17 & & & & 1.76 & & & & 0.02 & & & & 0.01 \\
\hline Potassium & vels & (C) & & & 0.56 & & & & 1.04 & & & & 0.01 & & & & 0.01 \\
\hline$(A) \times(B)$ & & & & & NS & & & & NS & & & & NS & & & & 0.02 \\
\hline$(A) \times(C)$ & & & & & 0.97 & & & & NS & & & & NS & & & & NS \\
\hline (B) $x(C)$ & & & & & NS & & & & NS & & & & NS & & & & NS \\
\hline (A) $x(B) x$ & & & & & NS & & & & NS & & & & NS & & & & NS \\
\hline
\end{tabular}


Table (4): Effect of irrigation, varieties, potassium levels and their interactions on number of millabe cane (thousand/fed) and cane yield (ton/fed) in 2008/2009 and 2009/2010 seasons.

\begin{tabular}{|c|c|c|c|c|c|c|c|c|c|c|c|c|c|c|c|c|c|}
\hline \multirow{4}{*}{$\begin{array}{l}\text { Irrigation } \\
\text { (A) }\end{array}$} & \multirow{4}{*}{$\begin{array}{c}\text { Sugar } \\
\text { cane } \\
\text { varieties } \\
(B) \\
\end{array}$} & \multicolumn{8}{|c|}{ Millable cane (thousand/fed) } & \multicolumn{8}{|c|}{ Cane yield (ton/fed) } \\
\hline & & \multicolumn{4}{|c|}{ 2008/2009 season } & \multicolumn{4}{|c|}{$2009 / 2010$ season } & \multicolumn{4}{|c|}{ 2008/2009 season } & \multicolumn{4}{|c|}{ 2009/2010 season } \\
\hline & & \multicolumn{3}{|c|}{ Potassium $\mathrm{kg} \mathrm{K}_{2} \mathrm{O}$ fed. (C) } & \multirow{2}{*}{ Mean } & \multicolumn{3}{|c|}{ Potassium $\mathrm{kg} \mathrm{K}_{2} \mathrm{O}$ fed. (C) } & \multirow{2}{*}{ Mean } & \multicolumn{3}{|c|}{ Potassium $\mathrm{kg} \mathrm{K}_{2} \mathrm{O}$ fed. (C) } & \multirow{2}{*}{ Mean } & \multicolumn{3}{|c|}{ Potassium $\mathrm{kg} \mathrm{K}_{2} \mathrm{O}$ fed. (C) } & \multirow{2}{*}{ Mean } \\
\hline & & 48 & 72 & 96 & & 48 & 72 & 96 & & 48 & 72 & 96 & & 48 & 72 & 96 & \\
\hline \multirow{2}{*}{$\begin{array}{c}\text { At } \\
75-80 \% \\
\text { FC }\end{array}$} & G.T.54-9 & 46.48 & 47.08 & 47.65 & 47.07 & 46.03 & 46.67 & 47.36 & 46.69 & 52.77 & 53.98 & 55.04 & 53.93 & 52.98 & 53.62 & 54.29 & 53.63 \\
\hline & G. 84-47 & 46.54 & 47.21 & 47.91 & 47.22 & 46.73 & 47.60 & 48.17 & 47.50 & 51.82 & 53.86 & 54.59 & 53.42 & 52.84 & 53.18 & 54.12 & 53.38 \\
\hline \multicolumn{2}{|c|}{ Mean } & 45.93 & 46.65 & 47.17 & 46.58 & 45.75 & 46.45 & 47.02 & 46.41 & 52.22 & 53.78 & 54.84 & 53.61 & 52.50 & 53.14 & 53.81 & 53.15 \\
\hline \multirow{2}{*}{$\begin{array}{c}\text { At } \\
60-65 \% \\
\text { FC }\end{array}$} & G.T.54-9 & 47.68 & 50.75 & 50.98 & 49.80 & 47.40 & 49.00 & 50.30 & 48.90 & 53.22 & 57.77 & 57.90 & 56.30 & 54.32 & 57.31 & 58.88 & 56.84 \\
\hline & G. 84-47 & 48.15 & 51.26 & 51.50 & 50.30 & 47.48 & 50.48 & 51.49 & 49.82 & 54.38 & 56.97 & 58.22 & 56.52 & 54.39 & 58.09 & 58.41 & 56.96 \\
\hline \multicolumn{2}{|c|}{ Mean } & 47.11 & 49.47 & 50.29 & 48.96 & 46.67 & 49.11 & 50.22 & 48.67 & 53.45 & 56.80 & 57.45 & 55.90 & 53.56 & 56.75 & 58.14 & 56.15 \\
\hline \multirow{3}{*}{$\begin{array}{c}\text { At } \\
45-50 \% \\
\text { FC }\end{array}$} & Ph 8013 & 44.17 & 45.51 & 45.97 & 45.22 & 43.84 & 44.91 & 45.08 & 44.61 & 51.47 & 52.75 & 53.40 & 52.54 & 50.57 & 51.92 & 52.26 & 51.58 \\
\hline & G.T.54-9 & 45.00 & 46.39 & 46.78 & 46.06 & 44.21 & 45.08 & 46.06 & 45.12 & 51.84 & 53.10 & 54.12 & 53.02 & 51.22 & 52.69 & 53.38 & 52.43 \\
\hline & G. 84-47 & 45.64 & 47.13 & 47.71 & 46.83 & 45.53 & 46.20 & 46.97 & 46.23 & 52.48 & 53.16 & 54.63 & 53.42 & 52.07 & 52.15 & 53.08 & 52.43 \\
\hline \multicolumn{2}{|c|}{ Mean } & 44.94 & 46.34 & 46.82 & 46.03 & 44.53 & 45.40 & 46.04 & 45.32 & 51.93 & 53.00 & 54.05 & 52.99 & 51.29 & 52.25 & 52.91 & 52.15 \\
\hline $\begin{array}{c}\text { Average } \\
\text { of } \\
\text { varieties }\end{array}$ & G. 84-47 & 46.77 & 48.53 & 49.04 & 48.12 & 46.58 & 48.09 & 48.88 & 47.85 & 52.90 & 54.66 & 55.81 & 54.46 & 53.10 & 54.47 & 55.20 & 54.26 \\
\hline \multicolumn{2}{|c|}{ Mean of potassium } & 45.99 & 47.49 & 48.09 & & 45.65 & 46.99 & 47.76 & & 52.53 & 54.53 & 55.44 & & 52.45 & 54.05 & 54.95 & \\
\hline \multicolumn{18}{|c|}{ LSD at 0.5 level for: } \\
\hline \multirow{2}{*}{\multicolumn{2}{|c|}{$\begin{array}{l}\text { Irrigation } \\
\text { Varieties }\end{array}$}} & & & & 0.47 & & & & 0.43 & & & & 0.49 & & & & 0.48 \\
\hline & & (B) & & & 0.26 & & & & 0.31 & & & & 0.24 & & & & 0.33 \\
\hline Potassium l & vels & (C) & & & 0.42 & & & & 0.28 & & & & 0.39 & & & & 0.23 \\
\hline$(A) \times(B)$ & & & & & 0.45 & & & & 0.54 & & & & 0.42 & & & & 0.56 \\
\hline (A) $x(C)$ & & & & & 0.35 & & & & 0.49 & & & & 0.69 & & & & 0.40 \\
\hline (B) $x(C)$ & & & & & 0.35 & & & & NS & & & & NS & & & & NS \\
\hline$(A) x(B) x$ & & & & & 0.61 & & & & NS & & & & NS & & & & 0.69 \\
\hline
\end{tabular}


significantly influenced by the $2^{\text {nd }}$ order interaction among the three studied factors, in the $1^{s t}$ season. Cane yield/fed. was significantly affected by the interaction among the three factors in the $2^{\text {nd }}$ season.

The highest number of millable canes and cane yield/fed. were mostly obtained by irrigating any of the tested sugarcane varieties at $60-65 \%$ $\mathrm{FC}$ and fertilizing them with $96 \mathrm{~kg} \mathrm{~K}_{2} \mathrm{O} /$ fed..

\subsection{Brix and sucrose percentages}

Results in Table (5) indicate that brix and sucrose percentages were significantly affected by the applied irrigation regimes. Irrigating sugarcane at $45-50 \% \mathrm{FC}$ resulted in the highest values of these quality characteristics, followed by irrigation at $60-65 \% \mathrm{FC}$ and irrigated at $75-80 \% \mathrm{FC}$, in both seasons, i.e. the more frequency of the irrigation the lower the values of brix and sucrose. This result may be due to the fact that keeping water content in cane stalks in a high level, decreases brix (total soluble solids) and/or sucrose, expressed as a percentage. These findings are in accordance with those found by Altaf UrRahman, et al. (1998).

Sugarcane G.84-47 variety significantly exceeded G.T.54-9 and Ph.8013 varieties, while the $2^{\text {nd }}$ and $3^{\text {rd }}$ rank in brix and sucrose percentages were alternatively replaced by G.T.54-9 and Ph.8013, in the $1^{\text {st }}$ and $2^{\text {nd }}$ seasons. The difference among cane varieties in these traits could be due to their genetic structure. El-Shafai and Ismail (2006), El-Sogheir et al. (2007), Ismail et al. (2008) and Ahmed et al. (2008) recorded differences among the tested cane varieties in these characters.

Brix and sucrose percentages were gradually and significantly increased accompanying the increase in potassium fertilization level given to sugarcane from 48 to 72 and $96 \mathrm{~kg} \mathrm{~K} \mathrm{~K}_{2} \mathrm{O} / \mathrm{fed}$. in both seasons. These results may be attributed to the role of $\mathrm{K}$ element as an activator in buildingup some enzymes participating in carbohydrate structure, in addition to its important role in transportation and storage of sugars in cane stalks. These results are in agreement with those reported by Abo El-Wafa et al. (2006), Bekheet (2006), Elamin, et al. (2007), Mahmoud et al. (2008) and Mokadem et al. (2010).

Brix percentage was significantly affected by the interaction between sugarcane varieties and $\mathrm{K}$ levels, in both seasons. However, sucrose \% was markedly influenced by this interaction in the $1^{\text {st }}$ one only.

\subsection{Sugar recovery percentage and sugar yield/fed.}

The results in Table (6) manifest that the used irrigation regimes significantly affected sugar recovery percentage and sugar yield/fed. in both seasons. The highest mean values of sugar recovery percentage was obtained by irrigating sugarcane at $45-50 \% \mathrm{FC}$, while the lowest ones were recorded by irrigation at $75-80 \% \mathrm{FC}$ in both seasons. Sugar recovery percentage was mainly affected by sucrose\% (Table 5), which had the same trend as responded to the studied watering regimes. Supplying sugarcane with irrigation water at $60-65 \%$ FC attained the highest sugar yield/fed., while adding irrigation at $75-80 \%$ FC recorded the lowest one in both seasons. Irrigating sugarcane at $60-65 \%$ FC gave 0.46 and 0.22 ton of sugar/fed. in the $1^{\text {st }}$ season, and 0.54 and 0.30 ton in the $2^{\text {nd }}$ one, over that produced by irrigating sugarcane at $75-80 \%$ FC and $45-50 \%$ FC, respectively. These results proved that cane yield (Table 4) is the most important component affecting sugar yield which had the same tendency as affected by the applied irrigation regimes. These findings are in accordance with those found by Altaf Ur-Rahman et al. (1998).

Sugarcane G.84-47 variety surpassed significantly G.T.54-9 and $\mathrm{Ph} .8013$ varieties in sugar recovery percentage and sugar yield/fed. in both seasons. Meanwhile, Ph.8013 variety recorded the lowest ones. Sugarcane G.84-47 variety produced 0.49 and 0.64 ton of sugar/fed., in the $1^{\text {st }}$ season and 0.25 and 0.41 ton of sugar/fed. in the $2^{\text {nd }}$ one higher than those given by G.T.54-9 and Ph.8013 varieties, successively. Moreover, it can be noticed that the difference between G.T.54-9 and Ph.8013 varieties in sugar recovery $\%$ was insignificant in the $2^{\text {nd }}$ season. The difference among cane varieties in these traits could be due to their genetic structure. El-Shafai and Ismail (2006), El-Sogheir et al. (2007), Ismail et al. (2008) and Ahmed et al. (2008) recorded differences among the tested cane varieties in these characters.

Sugar recovery percentage and sugar yield/fed. were gradually and significantly increased as a result of raising potassium fertilization level added to sugarcane from 48 to 72 and $96 \mathrm{~kg} \mathrm{~K}_{2} \mathrm{O} / \mathrm{fed}$. in both seasons. Sugarcane fertilized with $96 \mathrm{~kg} \mathrm{~K}_{2} \mathrm{O} /$ fed. produced 0.55 and 0.19 ton of sugar/fed., in the $1^{\text {st }}$ season and 0.64 and 0.29 ton/fed. In the $2^{\text {nd }}$ one higher than those obtained when sugarcane was supplied with 48 and $72 \mathrm{~kg} \mathrm{~K}_{2} \mathrm{O} /$ fed., respectively. These results may be attributed to the role of $\mathrm{K}$ element which similarly contributed in increasing cane yield 
Table (5): Effect of irrigation, varieties, potassium levels and their interactions on birx and sucrose percentages in $2008 / 2009$ and 2009/2010 seasons.

\begin{tabular}{|c|c|c|c|c|c|c|c|c|c|c|c|c|c|c|c|c|c|}
\hline \multirow{4}{*}{$\begin{array}{l}\text { Irrigation } \\
\text { (A) }\end{array}$} & \multirow{4}{*}{$\begin{array}{c}\text { Sugar } \\
\text { cane } \\
\text { varieties } \\
\text { (B) }\end{array}$} & \multicolumn{8}{|c|}{ Birx\% } & \multicolumn{8}{|c|}{ Sucrose\% } \\
\hline & & \multicolumn{4}{|c|}{ 2008/2009 season } & \multicolumn{4}{|c|}{ 2009/2010 season } & \multicolumn{4}{|c|}{ 2008/2009 season } & \multicolumn{4}{|c|}{ 2009/2010 season } \\
\hline & & \multicolumn{3}{|c|}{ Potassium $\mathrm{kg} \mathrm{K}_{2} \mathrm{O}$ fed. (C) } & \multirow{2}{*}{ Mean } & \multicolumn{3}{|c|}{ Potassium $\mathrm{kg} \mathrm{K}_{2} \mathrm{O}$ fed. (C) } & \multirow{2}{*}{ Mean } & \multicolumn{3}{|c|}{ Potassium $\mathrm{kg} \mathrm{K}_{2} \mathrm{O}$ fed. (C) } & \multirow{2}{*}{ Mean } & \multicolumn{3}{|c|}{ Potassium $\mathrm{kg} \mathrm{K}_{2} \mathrm{O}$ fed. (C) } & \multirow{2}{*}{ Mean } \\
\hline & & 48 & 72 & 96 & & 48 & 72 & 96 & & 48 & 72 & 96 & & 48 & 72 & 96 & \\
\hline \multirow{2}{*}{$\begin{array}{c}\text { At } \\
75-80 \% \\
\text { FC }\end{array}$} & G.T.54-9 & 19.74 & 20.15 & 20.27 & 20.05 & 19.11 & 19.72 & 19.94 & 19.59 & 16.98 & 17.46 & 17.58 & 17.34 & 16.32 & 16.92 & 17.39 & 16.88 \\
\hline & G. 84-47 & 20.81 & 21.40 & 22.04 & 21.42 & 19.78 & 19.99 & 21.03 & 20.27 & 17.88 & 18.42 & 19.00 & 18.43 & 17.16 & 17.23 & 18.27 & $\mathbf{1 7 . 5 5}$ \\
\hline \multicolumn{2}{|c|}{ Mean } & 20.03 & 20.50 & 20.81 & 20.45 & 19.35 & 19.71 & 20.22 & 19.76 & 17.23 & 17.72 & 17.98 & 17.64 & 16.62 & 16.91 & 17.53 & 17.02 \\
\hline \multirow{2}{*}{$\begin{array}{c}\text { At } \\
60-65 \% \\
\text { FC }\end{array}$} & G.T.54-9 & 20.28 & 20.49 & 20.70 & 20.49 & 19.46 & 19.98 & 20.35 & 19.93 & 17.48 & 17.56 & 17.90 & 17.68 & 16.80 & 17.36 & 17.61 & 17.26 \\
\hline & G. 84-47 & 21.82 & 22.77 & 22.99 & 22.53 & 19.98 & 20.47 & 20.95 & 20.46 & 18.87 & 19.63 & 19.91 & 19.47 & 17.28 & 17.80 & 18.33 & $\mathbf{1 7 . 8 0}$ \\
\hline \multicolumn{2}{|c|}{ Mean } & 20.64 & 21.22 & 21.43 & 21.10 & 19.68 & 20.15 & 20.58 & 20.14 & 17.82 & 18.28 & 18.54 & 18.22 & 17.03 & 17.49 & 17.87 & 17.46 \\
\hline \multirow{3}{*}{$\begin{array}{c}\text { At } \\
45-50 \% \\
\text { FC } \\
\end{array}$} & Ph 8013 & 20.19 & 20.68 & 20.92 & 20.60 & 20.10 & 20.52 & 21.32 & 20.65 & 17.68 & 17.88 & 18.05 & 17.87 & 17.41 & 17.83 & 18.57 & 17.94 \\
\hline & G.T.54-9 & 20.60 & 20.95 & 21.11 & 20.89 & 19.97 & 20.40 & 20.58 & 20.31 & 17.82 & 18.17 & 18.14 & 18.04 & 17.15 & 17.74 & 17.93 & 17.61 \\
\hline & G. 84-47 & 22.55 & 22.93 & 23.16 & 22.88 & 20.34 & 21.54 & 22.09 & 21.32 & 19.45 & 19.75 & 20.12 & 19.77 & 17.63 & 18.67 & 19.10 & 18.47 \\
\hline \multicolumn{2}{|c|}{ Mean } & 21.11 & 21.52 & 21.73 & 21.45 & 20.13 & 20.82 & 21.33 & 20.76 & 18.31 & 18.60 & 18.77 & 18.56 & 17.40 & 18.08 & 18.53 & 18.00 \\
\hline \multirow{2}{*}{$\begin{array}{c}\text { Average } \\
\text { of } \\
\text { varieties }\end{array}$} & G.T.54-9 & 20.21 & 20.53 & 20.69 & 20.48 & 19.51 & 20.03 & 20.29 & 19.94 & 17.43 & 17.76 & 17.87 & 17.69 & 16.76 & 17.34 & 17.65 & 17.25 \\
\hline & G. 84-47 & 21.73 & 22.36 & 22.73 & 22.28 & 20.03 & 20.67 & 21.35 & 20.68 & 18.73 & 19.26 & 19.68 & 19.22 & 17.36 & 17.90 & 18.56 & 17.94 \\
\hline \multicolumn{2}{|c|}{ Mean of potassium } & 20.59 & 21.08 & 21.32 & & 19.72 & 20.23 & 20.71 & & 17.79 & 18.20 & 18.43 & & 17.01 & 17.49 & 17.98 & \\
\hline \multicolumn{18}{|c|}{ LSD at 0.5 level for: } \\
\hline \multirow{2}{*}{\multicolumn{2}{|c|}{$\begin{array}{l}\text { Irrigation } \\
\text { Varieties }\end{array}$}} & & & & 0.26 & & & & 0.18 & & & & 0.22 & & & & 0.11 \\
\hline & & (B) & & & 0.39 & & & & 0.31 & & & & 0.32 & & & & 0.30 \\
\hline Potassium l & vels & (C) & & & 0.10 & & & & 0.16 & & & & 0.10 & & & & 0.16 \\
\hline$(A) \times(B)$ & & & & & NS & & & & NS & & & & NS & & & & NS \\
\hline$(A) x(C)$ & & & & & NS & & & & NS & & & & NS & & & & NS \\
\hline (B) $x(C)$ & & & & & 0.17 & & & & 0.28 & & & & 0.18 & & & & NS \\
\hline (A) $x(B) x$ & & & & & NS & & & & NS & & & & NS & & & & NS \\
\hline
\end{tabular}


Table (6): Effect of irrigation, varieties, potassium levels and their interactions on sugar recovery\% and sugar yield (ton/fed.) in 2008/2009 and 2009/2010 seasons.

\begin{tabular}{|c|c|c|c|c|c|c|c|c|c|c|c|c|c|c|c|c|c|}
\hline \multirow{4}{*}{$\begin{array}{l}\text { Irrigation } \\
\text { (A) }\end{array}$} & \multirow{4}{*}{$\begin{array}{c}\text { Sugar } \\
\text { cane } \\
\text { varieties } \\
\text { (B) }\end{array}$} & \multicolumn{8}{|c|}{ Sugar recovery\% } & \multicolumn{8}{|c|}{ Sugar yield (ton/fed) } \\
\hline & & \multicolumn{4}{|c|}{ 2008/2009 season } & \multicolumn{4}{|c|}{$2009 / 2010$ season } & \multicolumn{4}{|c|}{ 2008/2009 season } & \multicolumn{4}{|c|}{$2009 / 2010$ season } \\
\hline & & \multicolumn{3}{|c|}{ Potassium $\mathrm{kg} \mathrm{K}_{2} \mathrm{O}$ fed. (C) } & \multirow{2}{*}{ Mean } & \multicolumn{3}{|c|}{ Potassium kg $\mathrm{K}_{2} \mathrm{O}$ fed. (C) } & \multirow{2}{*}{ Mean } & \multicolumn{3}{|c|}{ Potassium $\mathrm{kg} \mathrm{K}_{2} \mathrm{O}$ fed. (C) } & \multirow{2}{*}{ Mean } & \multicolumn{3}{|c|}{ Potassium $\mathrm{kg} \mathrm{K}_{2} \mathrm{O}$ fed. (C) } & \multirow{2}{*}{ Mean } \\
\hline & & 48 & 72 & 96 & & 48 & 72 & 96 & & 48 & 72 & 96 & & 48 & 72 & 96 & \\
\hline \multirow{2}{*}{$\begin{array}{c}\text { At } \\
75-80 \% \\
\text { FC }\end{array}$} & G.T.54-9 & 11.08 & 11.37 & 11.45 & 11.30 & 10.52 & 10.93 & 11.41 & 10.95 & 5.85 & 6.14 & 6.30 & 6.10 & 5.57 & 5.86 & 6.20 & 5.88 \\
\hline & G. 84-47 & 11.52 & 11.86 & 12.23 & 11.87 & 11.21 & 11.17 & 11.89 & 11.42 & 5.97 & 6.39 & 6.67 & 6.34 & 5.92 & 5.94 & 6.43 & 6.10 \\
\hline \multicolumn{2}{|c|}{ Mean } & 11.17 & 11.50 & 11.65 & 11.44 & 10.76 & 10.92 & 11.42 & 11.03 & 5.83 & 6.18 & 6.39 & 6.13 & 5.65 & 5.81 & 6.15 & 5.87 \\
\hline \multirow{2}{*}{$\begin{array}{c}\text { At } \\
60-65 \% \\
\text { FC }\end{array}$} & G.T.54-9 & 11.32 & 11.42 & 11.61 & 11.45 & 10.93 & 11.34 & 11.45 & 11.24 & 6.03 & 6.59 & 6.72 & 6.45 & 5.94 & 6.50 & 6.74 & 6.39 \\
\hline & G. 84-47 & 12.19 & 12.60 & 12.83 & 12.54 & 11.24 & 11.61 & 12.19 & 11.68 & 6.63 & 7.18 & 7.47 & 7.09 & 6.12 & 6.75 & 7.12 & 6.66 \\
\hline \multicolumn{2}{|c|}{ Mean } & 11.55 & 11.79 & 12.01 & 11.78 & 11.09 & 11.41 & 11.71 & 11.40 & 6.18 & 6.70 & 6.90 & 6.59 & 5.94 & 6.48 & 6.81 & 6.41 \\
\hline \multirow{3}{*}{$\begin{array}{c}\text { At } \\
45-50 \% \\
\text { FC }\end{array}$} & Ph 8013 & 11.63 & 11.60 & 11.67 & 11.64 & 11.34 & 11.63 & 12.10 & 11.69 & 5.99 & 6.12 & 6.24 & 6.11 & 5.74 & 6.04 & 6.33 & 6.03 \\
\hline & G.T.54-9 & 11.56 & 11.80 & 11.69 & 11.68 & 11.08 & 11.59 & 11.73 & 11.47 & 5.99 & 6.27 & 6.32 & 6.20 & 5.68 & 6.11 & 6.26 & 6.02 \\
\hline & G. 84-47 & 12.50 & 12.66 & 12.99 & 12.72 & 11.48 & 12.11 & 12.33 & 11.97 & 6.56 & 6.73 & 7.10 & 6.80 & 5.98 & 6.31 & 6.54 & 6.28 \\
\hline \multicolumn{2}{|c|}{ Mean } & 11.90 & 12.02 & 12.12 & 12.01 & 11.30 & 11.78 & 12.05 & 11.71 & 6.18 & 6.37 & 6.55 & 6.37 & 5.80 & 6.15 & 6.38 & 6.11 \\
\hline $\begin{array}{c}\text { Average } \\
\text { of } \\
\text { varieties }\end{array}$ & G. 84-47 & 12.07 & 12.37 & 12.68 & 12.38 & 11.31 & 11.65 & 12.14 & 11.69 & 6.39 & 6.77 & 7.08 & 6.74 & 6.01 & 6.33 & 6.70 & 6.35 \\
\hline \multicolumn{2}{|c|}{ Mean of potassium } & 11.54 & 11.77 & 11.93 & & 11.05 & 11.37 & 11.73 & & 6.06 & 6.42 & 6.61 & & 5.80 & 6.15 & 6.44 & \\
\hline \multicolumn{18}{|c|}{ LSD at 0.5 level for: } \\
\hline \multirow{2}{*}{\multicolumn{2}{|c|}{$\begin{array}{l}\text { Irrigation } \\
\text { Varieties }\end{array}$}} & & & & 0.15 & & & & 0.05 & & & & 0.18 & & & & 0.08 \\
\hline & & (B) & & & 0.19 & & & & 0.19 & & & & 0.11 & & & & 0.13 \\
\hline Potassium I & els & (C) & & & 0.09 & & & & 0.11 & & & & 0.07 & & & & 0.06 \\
\hline$(A) \times(B)$ & & & & & NS & & & & NS & & & & 0.20 & & & & NS \\
\hline$(A) \times(C)$ & & & & & NS & & & & NS & & & & 0.12 & & & & 0.11 \\
\hline (B) $\times(C)$ & & & & & 0.16 & & & & NS & & & & 0.12 & & & & NS \\
\hline$(A) x(B) x$ & & & & & NS & & & & NS & & & & NS & & & & NS \\
\hline
\end{tabular}


Table (7): Effect of irrigation, varieties, potassium levels their interactions on water consumptive use $\mathbf{m}^{3} /$ fed., water use efficiency on cane and sugar yields basis ( $\mathrm{kg}$ cane $\mathrm{stalk} / \mathrm{m}^{3}$ water consumed) in 2008/2009 and 2009/2010 seasons.

\begin{tabular}{|c|c|c|c|c|c|c|c|c|c|c|c|c|c|c|c|c|c|c|c|c|c|c|c|c|c|}
\hline \multirow{4}{*}{$\begin{array}{l}\text { Irrigation } \\
\text { (A) }\end{array}$} & \multirow{4}{*}{$\begin{array}{c}\text { Sugar } \\
\text { cane } \\
\text { varieties } \\
\text { (B) }\end{array}$} & \multicolumn{8}{|c|}{ Water consumptive use $\mathbf{m}^{3} /$ fed. } & \multicolumn{8}{|c|}{$\begin{array}{l}\text { water use efficiency on cane yield basis (kg } \\
\text { cane stalk/m } / \mathrm{m}^{3} \text { water consumed) }\end{array}$} & \multicolumn{8}{|c|}{$\begin{array}{c}\text { water use efficiency on sugar yield basis (kg } \\
\text { sugar } / \mathrm{m}^{3} \text { water consumed) }\end{array}$} \\
\hline & & \multicolumn{4}{|c|}{ 2008/2009 season } & \multicolumn{4}{|c|}{$2009 / 2010$ season } & \multicolumn{4}{|c|}{ 2008/2009 season } & \multicolumn{4}{|c|}{$2009 / 2010$ season } & \multicolumn{4}{|c|}{ 2008/2009 season } & \multicolumn{4}{|c|}{$2009 / 2010$ season } \\
\hline & & \multicolumn{3}{|c|}{$\begin{array}{l}\text { Potassium kg } \\
\mathrm{K}_{2} \mathrm{O} \text { fed. }(\mathrm{C})\end{array}$} & \multirow{2}{*}{ 当 } & \multicolumn{3}{|c|}{$\begin{array}{l}\text { Potassium kg K } \mathrm{K}_{2} \mathrm{O} \\
\text { fed. (C) }\end{array}$} & \multirow{2}{*}{$\sum_{\Sigma}^{\Xi}$} & \multicolumn{3}{|c|}{$\begin{array}{l}\text { Potassium kg } \\
\mathrm{K}_{2} \mathrm{O} \text { fed. }(\mathrm{C})\end{array}$} & \multirow{2}{*}{$\sum^{\Xi}$} & \multicolumn{3}{|c|}{$\begin{array}{l}\text { Potassium kg } \\
\mathrm{K}_{2} \mathrm{O} \text { fed. }(\mathrm{C})\end{array}$} & \multirow{2}{*}{$\sum_{\tilde{\Sigma}}^{\tilde{\Xi}}$} & \multicolumn{3}{|c|}{$\begin{array}{l}\text { Potassium kg } \\
\mathrm{K}_{2} \mathrm{O} \text { fed. (C) }\end{array}$} & \multirow{2}{*}{$\sum_{\tilde{E}}^{\mathbb{E}}$} & \multicolumn{3}{|c|}{$\begin{array}{l}\text { Potassium kg } \\
\mathrm{K}_{2} \mathrm{O} \text { fed. (C) }\end{array}$} & \multirow{2}{*}{$\sum^{\tilde{E}}$} \\
\hline & & 48 & 72 & 96 & & 48 & 72 & 96 & & 48 & 72 & 96 & & 48 & 72 & 96 & & 48 & 72 & 96 & & 48 & 72 & 96 & \\
\hline \multirow{3}{*}{$\begin{array}{c}\text { At } \\
75-80 \% \\
\text { FC }\end{array}$} & Ph 8 & 90.4 & 863 & 6 & 55.8 & 5 & 7 & 0 & 8657.7 & 5 & 6.19 & 6 & 6 & 587 & that & 6.22 & 6.06 & 0.6 & 77 & 5 & 0.70 & 0.62 & 65 & 0.68 & 0.65 \\
\hline & G.T. 54-9 & 00.8 & 8370.6 & 40.5 & 37.3 & 60.7 & 28.1 & 90.6 & 93.1 & 0.21 & 6.4 & 6.72 & 6.46 & 0.19 & 6.60 & 6.80 & 0.55 & 0.6 & 0.15 & 0.77 & 0.73 & 0.03 & 0.12 & 0.78 & 0.72 \\
\hline & G. 8 & 210.7 & 8000.9 & 7890.6 & 8034.1 & 8260.6 & 8070.8 & 7880.4 & 8070.6 & 6.31 & 6 & 6.92 & 6.65 & 6.40 & 6.59 & 6.87 & 6.61 & 0.7 & 1.80 & 0.85 & 0.79 & 0.1 & 0.74 & 0.82 & 0.76 \\
\hline \multicolumn{2}{|c|}{ Mean } & 8500.6 & 8336.7 & 8089.9 & 8309.1 & 8543.9 & 8279.2 & 8090.3 & 8307.1 & 6.14 & 6.4 & 6.78 & 6.45 & 6 & 6.42 & 6.65 & 6.4 & 0 & 0.74 & 0.79 & 0.74 & .66 & 0.70 & 0.76 & 0.71 \\
\hline \multirow{3}{*}{$\begin{array}{c}\text { At } \\
60-65 \% \\
\text { FC }\end{array}$} & 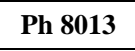 & 30.4 & 8178.5 & 78.0 & 95.6 & 54.8 & 8.3 & 88.7 & 13.9 & 6.33 & 6 & 7.23 & 6.7 & 6. & 6.69 & 7.06 & 6.1 & 0.7 & 0.77 & 0.84 & 0 & 0.69 & 0.75 & 0.81 & 0.75 \\
\hline & G.T. & 660.8 & 7930.9 & 7755.9 & \begin{tabular}{|l|}
7915.9 \\
\end{tabular} & 8115.3 & 7945.3 & 7840.4 & 7967.0 & 6.60 & 7.28 & 7.47 & 7.11 & 6.6 & 6.21 & 7.51 & 7.13 & 0.1 & 0.83 & 0.87 & 0. & 0.73 & 0.82 & 0.86 & 0.80 \\
\hline & G. 84-47 & 7840.7 & 7690.2 & 7534.5 & 7688.5 & 8005.5 & 7890.6 & 7806.7 & 7900.9 & 6.94 & 7.41 & 7.73 & 7.36 & 6.74 & 7.36 & 7.48 & 7.21 & 0.8 & 0.93 & 0.99 & 0.92 & 0.76 & 0.86 & 0.91 & 0.84 \\
\hline Me & & 8077.3 & 7933.2 & 7689.5 & 7900.0 & 8158.5 & 8011.4 & 7911.9 & 8027.3 & 6.62 & 7.16 & 7.47 & 7.08 & 6.5 & 7.08 & 7.35 & 6.99 & 0.7 & 0.84 & 0.90 & 0.8 & 0.7 & 0.81 & 0.86 & 0.80 \\
\hline & Ph 8013 & 4 & 7 & 7 & .5 & 1 & 7 & 7 & 7 & 6 & 6 & 6.9 & 6 & 6.34 & 6 & 6.7 & 6 & 0 & 0 & 0 & 0 & 0 & 0 & 0.82 & 0.77 \\
\hline & G & 40.3 & 7598.8 & 7492.9 & 7610.7 & 7690.8 & 7535.9 & 7427.7 & 7 & 6.69 & 6 & 7.22 & 6.94 & 0 & 6.99 & 1.19 & 4 & 0.7 & 0.83 & 34 & 0.81 & 0.74 & 1 & 0.84 & .80 \\
\hline & G. 84-47 & 7560.7 & 7401.4 & 7275.4 & 7412.5 & 7590.9 & 7446.7 & 7358.4 & 7465.5 & 6.94 & 7.18 & 7.51 & 7.21 & 6.86 & 7.00 & 7.21 & 7.02 & 0.8 & 0.91 & 0.98 & 0.92 & 0.79 & 0.85 & 0.89 & 0.84 \\
\hline Me & & 7750.5 & \begin{tabular}{|l|}
7591.3 \\
\end{tabular} & \begin{tabular}{|l|l|}
7473.9 \\
\end{tabular} & 7605.2 & \begin{tabular}{|l|}
7753.9 \\
\end{tabular} & \begin{tabular}{|l|}
7605.9 \\
\end{tabular} & \begin{tabular}{|l|}
7504.4 \\
\end{tabular} & 7621.4 & 6.68 & 6.98 & 7.23 & 6.97 & 6.61 & 6.87 & 7.05 & 6.81 & 0.8 & 0.84 & 0.88 & 0.84 & 0.77 & 0.81 & 0.85 & 0.81 \\
\hline & Ph 8013 & 357.1 & 8196.9 & 7890.0 & 8109.6 & 8381.8 & 8224.1 & 8113.3 & 8 & 6.23 & 6 & 6 & 0. & 6.13 & 6 & 6. & 0. & 0.7 & 0.75 & 0.80 & 0 & 0.67 & 2 & 0.77 & 0.72 \\
\hline & G.T. 54-9 & 8100.6 & 7966.8 & 7796.4 & 7953.7 & 8122.3 & 7869.8 & 7767.6 & 7919.9 & 6.49 & 6.90 & 7.1 & 6.84 & 0.3 & 6.93 & 7.1 & 6.86 & 0. & 0.19 & 0.83 & 0.79 & 0. & 0.78 & 0.82 & 0.77 \\
\hline & G. 84-47 & 7870.7 & 7697.5 & 7954.6 & 7711.7 & 7952.3 & 7802.7 & 7681.8 & 7812.3 & 6.72 & 7.10 & 7.38 & 7.06 & 6.68 & 6.98 & 7.19 & 6.94 & 0.8 & 0.85 & 0.94 & 0.87 & 0.76 & 0.81 & 0.87 & 0.81 \\
\hline Mear & ssium & 8109.6 & \begin{tabular}{|l|}
7953.7 \\
\end{tabular} & 7751.1 & & 8152.1 & 7965.5 & 7854.2 & & 6.48 & \begin{tabular}{|l|}
6.86 \\
\end{tabular} & 7.15 & & 6.43 & 6.78 & 6.49 & & 0.7 & 0.81 & 0.85 & & 0 . & 0.77 & 0.82 & \\
\hline
\end{tabular}


(Table 4) and sugar recovery\% (Table 6), which are the components of sugar yield. These results are in agreement with those reported by Abo ElWafa et al. (2006), Bekheet (2006), Elamin et al. (2007), Mahmoud et al. (2008) and Mokadem et al. (2010).

Sugar yield/fed. was significantly affected by the interaction between irrigation regimes and cane varieties in the $1^{\text {st }}$ season. Moreover, this trait was significantly influenced by the interaction between irrigation treatments $\mathrm{x} K$ fertilization levels in both seasons. Sugar recovery percentage and sugar yield/fed. were significantly affected by cane varieties $\mathrm{x} \mathrm{K}$ levels interaction in the $1^{s t}$ season.

The highest sugar yield/fed. was produced by planting G.84-47 variety, irrigated at $60-65 \%$ FC and fertilized with potassium at the rate of $96 \mathrm{~kg}$ $\mathrm{K}_{2} \mathrm{O} /$ fed.

\subsection{Water consumptive use}

The results in Table (7) point out that sugarcane water consumptive use increased by 409.1 and $703.9 \mathrm{~m}^{3}$ of water in the case of applying irrigation at $75-80 \% \mathrm{FC}$ compared with that irrigated at $60-65 \% \mathrm{FC}$ and/or $45-50 \% \mathrm{FC}$ in the $1^{\text {st }}$ season, corresponding to 279.8 and 685.7 $\mathrm{m}^{3}$ water, in the $2^{\text {nd }}$ one, respectively.

The highest water consumptive use was recorded by $\mathrm{Ph} .8013$ variety which exceeded G.T.54-9 and G.84-47 sugarcane varieties by 193.4 and $436.3 \mathrm{~m}^{3}$ water in the $1^{\text {st }}$ season and 319.8 and $427.4 \mathrm{~m}^{3}$ water, in the $2^{\text {nd }}$ one, successively.

Raising potassium fertilization level 48 to 72 and $96 \mathrm{~kg} \mathrm{~K}_{2} \mathrm{O} / \mathrm{fed}$. decreased the amount of water consumed by sugarcane plants by 155.9 and 358.5 $\mathrm{m}^{3}$ water in the $1^{\text {st }}$ season, corresponds 186.6 and $297.9 \mathrm{~m}^{3}$ water, in the $2^{\text {nd }}$ one, respectively. These results may be due to the fact that high concentrations of $\mathrm{K}$ element occur in meristematic tissues and stomatal guard cells and that potassium is involved in turgor control in specialized cells in the leaves (Anderson and Bowen, 1990), which may led to a reduction in the amount of water lost to the air by transpiration from plant foliage surface.

\subsection{Water use efficiency:}

The results in Table (7) indicate that water use efficiency (WUE) calculated on cane-yield basis reached its maximum value when irrigation was given to sugarcane at 60-65 \% FC followed by that applied at $45-50 \%$ and $75-80 \%$ FC. These results could be due to the same tendency of cane yield obtained corresponding to the respective irrigation levels, respectively (Table 4). In the case of calculating of WUE on sugar-yield basis, it was found that WUE values correspond the $1^{\text {st }}$ and $2^{\text {nd }}$ irrigation treatments (applying irrigation at 70-75 $\%$ FC and 60-65 \% FC) had the same trend of sugar yield (Table 6). However, WUE values were the highest when irrigation was applied at 45-50 $\%$ FC which might be attributed to that the amounts of water consumed by cane plants were the lowest at this regime (Table 7).

In conclusion, under the conditions of the present work, irrigating sugarcane variety G.84-47 at $60-65 \% \mathrm{FC}$ and fertilizing it with potassium at the rate of $72 \mathrm{~kg} \mathrm{~K}_{2} \mathrm{O} / \mathrm{fed}$. cane are recommended to get the highest cane and sugar yields/fed.

\section{REFERENCES}

Abdel Wahab D.M. (2005). Effect of irrigation at different soil moisture levels on yield of sugarcane at Kenana sugar scheme. Proceedings of the meeting of the National Crop Husbandry Committee $40^{\text {th }}$, Wad Medani, Sudan, pp. 187-201.

Abo El-Wafa A.M., Ferweez H. and Mohamed K.E. (2006). Effect of potassium fertilizer levels on the productivity, quality and profitability of promising $\mathrm{Ph} 8013$ sugarcane clone compared with the commercial G.T.54-9 sugarcane cultivar. Bulletin Fac. Agric. Cairo Univ., 57 (3): 383-399.

Ahmed A.Z., Osman M.S.H. and Mohamed A. (2008). Effect of excessive nitrogen application on yield and quality of three sugarcane varieties. Intern. Conf. "IS-2008" Meeting the Challenges of Sugar Crops \& Integrated Industries in Developing Countries. Held at Sinai Univ., 11-14 Sep., 2008, Al-Arish, Egypt. pp. 34-39.

Altaf Ur-Rahman U.R.M., Said R. and Rehman S. (1998). Effect of nitrogen fertilization and irrigation on the juice quality of sugarcane. Pakistan Sugar J., 12 (2): 24-28.

Anderson D.L. and Bowen J.E. (1990). Sugarcane Nutrition. Published by Potash \& Phosphate Institute, 655 Engineering Drive, Suite 110, Norcross, Georgia 30092, USA.

A.O.A.C. (1995). Official methods of analysis, puplished by the A.O.A.C., Box 540, Washington, D.C.

Bekheet M.A. (2006). Effect of irrigation and potassium fertilization on yield and quality of two sugarcane varieties. Assiut J. Agric. Sci., 37(1): 1-19.

Elamin E.A., El-Tilip M.A., Elnasikh M.H., Ibrahium S.H., Elsheikh M.A. and Babiker E.E. (2007). The influence of phosphorus and 
potassium fertilization on quality of sugar of two sugarcane varieties grown on three soil series of Sudan. J. Applied Sci., 7 (16): 23452350.

El-Shafai A.M.A. and Ismail A.M.A. (2006). Effect of row spacing on yield and quality of some promising sugarcane varieties. Egypt J. Appl. Sci., 21 (11): 32-46.

El-Sogheir K.S., Ahmed A.Z. and Shalaby N.M.N. (2007). Performance of some sugarcane varieties at different planting dates. $8^{\text {th }}$ African Crop Sci. Soc. Conf., 27-31 Oct. Minia, Egypt.

Freed R.S.P., Eisensmith S.P., Goetez S., Recosky D., Smail V.W. and wolberg P. (1989). User's Guide MSTAT-C A software program for the design management and analysis of agronomic research experiments. Michigan State University, U.S.A.

Gomez K.A. and Gomez A.A. (1984). Statistical procedures for agricultural research. $2^{\text {nd }} \mathrm{Ed}$., John Wiley and Sons, New York, USA.

Ibrahim H.S. (2006). Determination of irrigation interval for sugarcane by monitoring changes in soil moisture in the field at the Guneid Scheme. Proceedings of the meeting of the National Crop Husbandry Committee $37^{\text {th }}$, Wad Medani, Sudan , pp. 52-60.

Ismail A.M.A. and El-Sogheir K.S. (2008). Seed sets of plant and rations crop in relation to varietal performance of three sugarcane varieties. Egypt J. Appl. Sci., 23 (2-b):500-513.
Ismail A.M.A., Bekheet M.A. and Abo El-Hamd A.S. (2008). Yield and quality of four sugarcane varieties as influensed by seed rate and nitrogen fertilization. Egypt J. Appl. Sci., 23 (1):107-123.

Israelsen O.W. and Hansen V.E. (1962). Irrigation principles and practices. $3^{\text {rd }}$ John Wiley and Sons Inc., New York.

Jackson M.L. (1973). Soil chemical analysis. Prentice Hall, Inc., Englewood cliffs, N. J., USA.

Mahmoud S.A.,Hasanin B., El-Geddawy I.H. and Mustafa M.F.A. (2008). Effect of some fertilization treatments on productivity and quality of the newly released sugarcane variety (PHIL.8013). Meeting the challenges of sugar crops and integrated industries in the developing countries. Al Arish, Egypt. pp 3-13.

Mokadem Sh.A., Bekheet M.A., Tantawy A.A., Salem M.A. and Ali S.A.M. (2010). Yield and quality of sugar cane as affected by potassium levels and date of applying the first postplanting and with holding irrigation. Minia $2^{\text {nd }}$ Conf. Agric. Environ. Sci. (March 22-24): 1328.Minia , Egypt.

Vites F.G. Jr. (1965). Increasing water use efficiency by soil management. Amer. Soc. Agron., Madison, Wisc., P. 259-274.

Yadav R.L. and Sharma R.K. (1980). Effect of nitrogen level and harvesting date on quality characteristics and yield of four sugar cane genotypes. Indian J. Agric. Sci., 50: 581-589.

$$
\begin{aligned}
& \text { تأثير نقص رطوبة التربة والتسميد البوتاسى على العلاقات المائية } \\
& \text { كمل أبوبكر بخيت } \\
& \text { معهد بحوث المحاصيل السكرية ـ مركز البحوث الزر اعبة ـ الجيزة ـ مصر }
\end{aligned}
$$

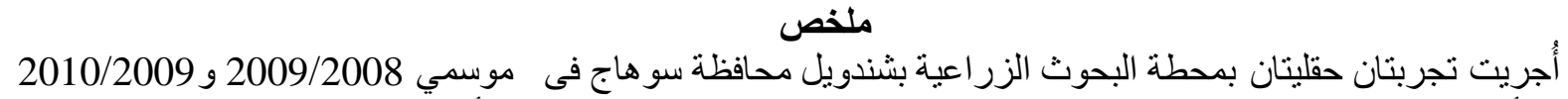

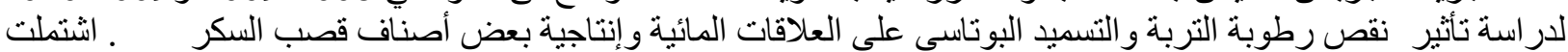

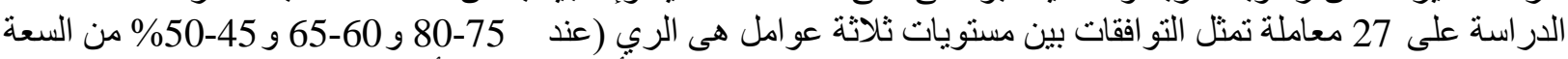

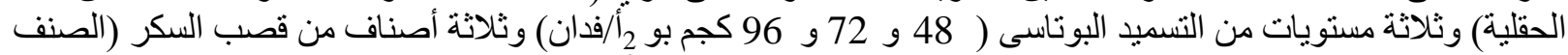

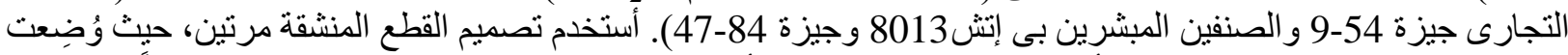

$$
\begin{aligned}
& \text { معاملات الرى فى القطع الرئيسية والأصناف فى القطع المنشقة الأولى، ووزين عت معدلات التسميد البوتاسى عشو ائياً فى القطع } \\
& \text { المنشقة الثانية }
\end{aligned}
$$

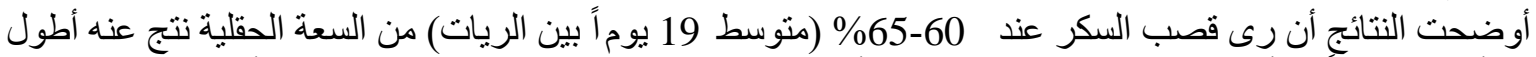

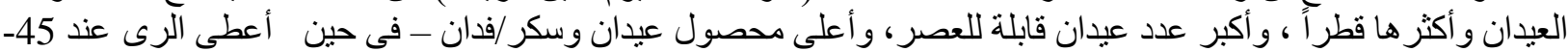

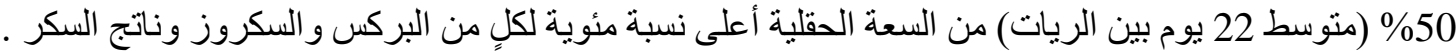


بلغ الإستهلاك المائى لقصب السكر 8307.1 و 7621.4 م3 /فدان عندما تم الرى عند 75-80\% (متوسط 17 يوم بين

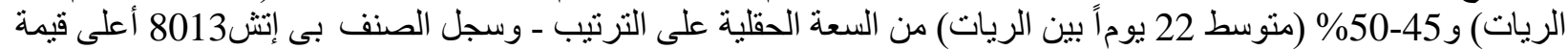

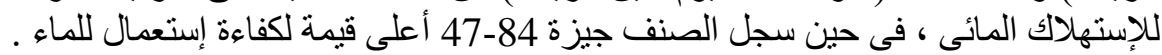

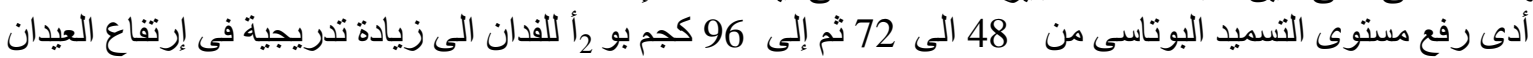

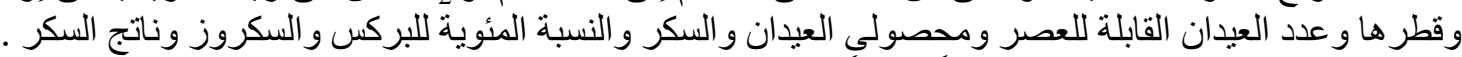

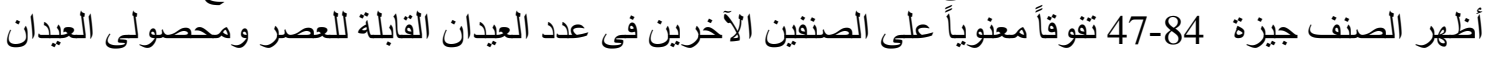

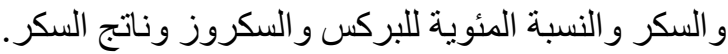

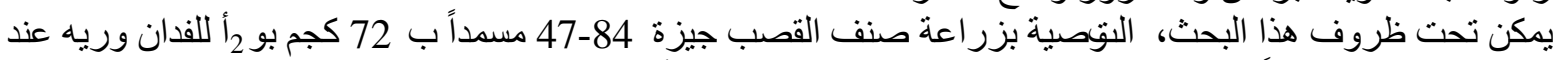
65-60\% (متوسط 19 يوماً بين الريات) من السعة الحقلية للحصول على على أعلى العلى محصول من العيدان والسكر.

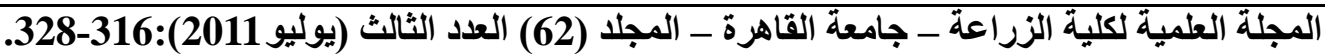

